\title{
Interactions between negative energy balance, metabolic diseases, uterine health and immune response in transition dairy cows
}

\author{
Giulia Esposito $^{1,2,3}$, Pete C. Irons ${ }^{1,3}$, Edward C. Webb ${ }^{2,3}$ and Aspinas Chapwanya ${ }^{1,3^{*}}$ \\ ${ }^{1}$ Department of Production Animal Studies, Faculty of Veterinary Science, University of Pretoria, South Africa. \\ ${ }^{2}$ Department of Animal \& Wildlife Sciences, Faculty of Natural \& Agricultural Sciences, University of Pretoria, South Africa. \\ ${ }^{3}$ Institute of Food, Nutrition and Well-being (IFNuW), University of Pretoria, South Africa. \\ *Corresponding author. Email: chapwana@tcd.ie, Telephone: 0027125298084, Fax: 002712528071 Address: Department of \\ Production Animal Studies, Faculty of Veterinary Science, University of Pretoria, Onderstepoort, Pretoria, South Africa.
}

\begin{abstract}
The biological cycles of milk production and reproduction determine dairying profitability thus making management decisions dynamic and time-dependent. Diseases also negatively impact on net earnings of a dairy enterprise. Transition cows in particular face the challenge of negative energy balance (NEB) and/or disproportional energy metabolism (fatty liver, ketosis, subacute, acute ruminal acidosis); disturbed mineral utilization (milk fever, sub-clinical hypocalcemia); and perturbed immune function (retained placenta, metritis, mastitis). Consequently NEB and reduced dry matter intake are aggravated. The combined effects of all these challenges are reduced fertility and milk production resulting in diminishing profits. Risk factors such as NEB, inflammation and impairment of the immune response are highly cause-and-effect related. Thus, managing cows during the transition period should be geared towards reducing NEB or feeding specially formulated diets to improve immunity. Given that all cows experience a reduced feed intake and body condition, infection and inflammation of the uterus after calving, there is a need for further research on the immunology of transition dairy cows. Integrative
\end{abstract}


approaches at the molecular, cellular and animal level may unravel the complex interactions between disturbed metabolism and immune function that predispose cows to periparturient diseases.

\section{Key words}

PUFA, negative energy balance, metritis, endometritis, transition cows

\section{Introduction}

Whereas the dry period in cows may be considered to be a resting phase between lactations, in reality considerable fetal growth, mammary tissue remodeling and high nutritional demands occur. The recognition of the importance of the period from late pregnancy until the adaptation phase of early lactation has led to the development of the concept of the transition period, which is commonly defined as the period from 3 weeks before to 3 weeks after calving (Drackley, 1999). Nutrient requirements of the fetus reach maximal levels three weeks prepartum, yet dry matter intake (DMI) decreases by 10 to $30 \%$ (Bell, 1995). Within three weeks of the onset of lactation, milk yield, milk proteins, fat and lactose increase rapidly and exceed feed intake (Bertoni et al., 2009). Moreover, the diet of most dairy cows changes sharply at calving from being mainly forage-based to concentrate-rich diets. Postpartum milk production and the requisite nutritional adaptations induce a physiological state of negative energy balance (NEB). In recent times, genetic selection and improved nutrition have increased milk yield per cow. However, the increased milk output has been accompanied by a decline in fertility in many countries. Pregnancy rates after insemination have declined by $0.45 \%-1 \%$ annually in UK and Northern American herds (Royal et al., 2000; Butler et al., 2003; Dobson et al., 2007) while the culling rate is 20 to 35\% (Smith et al., 2000; Rajala-Schultz and Frazer, 2003). Thus, the conclusion reached by many is the existence of an overall antagonism between milk yield and reproduction (VanRaden et al., 2004; Chagas 
et al., 2007; Lucy, 2007; McCarthy et al., 2007; Mee, 2007). However, recent studies now provide evidence for high milk yield not necessarily being associated with low fertility (López-Gatius et al., 2003, 2006; Patton et al., 2007). An USDA study has shown that fertility of dairy cattle in Northern America has rebounded since the incorporation of genetic merit for daughter pregnancy rate (DPR) with no apparent slowing down in milk yield and fertility (VanRaden et al., 2011).

There is no arguing that milk yield and reproductive performance are the standard economic barometers of dairy production. It is thought that the reproductive status of a cow is the single most important factor influencing culling decisions on farms and that uterine infection likely contributes indirectly to the high rates of involuntary culling (Gröhn et al., 2003). Understanding the key role of immune responses in numerous transition cow disorders may help to explain links between these diverse conditions. At the molecular level, the activation of local and systemic host defense mechanisms induce inflammation; furthermore, significant gene expression changes occur as an adaptation to the demands of lactation, maintenance and the rapidly involuting uterus. A host of signaling molecules are released by activated immune cells including inflammatory mediators such as prostaglandins and cytokines. The systemic levels of immune molecules such as haptoglobin (HP) and Interleukin 8 (IL8) are significantly elevated around calving (Bionaz et al., 2007; Bertoni et al., 2008; Huzzey, 2009). Cows even show typical inflammatory changes prior to calving (Trevisi et al., 2002; Trevisi and Bertoni, 2008). Cytokines play a key role in stimulating systemic inflammatory responses, including increased body temperature and heart rate, and decreased feed intake (Dantzer and Kelley, 2007). Furthermore, given the interplay between the immune, endocrine and metabolic systems (Stofkova, 2009; Pittman, 2011), diminished immune competence at calving increases host susceptibility to infections (Trevisi et al., 2011). 
Physiological conditions associated with insufficient energy supply predispose dairy cows to metabolic and microbial diseases such as milk fever, endometritis, ketosis, displaced abomasum and retained placenta (Drackley, 1999; Duffield and Herdt, 2000). Clearly the role of inflammatory responses in the decline in fertility is not known, given the range of effects on various physiological processes. An improved understanding of the inflammatory pathways at the molecular level which play an important role in normal immune function, metabolism and reproduction may improve our ability to predict and prevent transition cow disorders. The major interactions between the immune, endocrine and metabolic systems in dairy cows during the transition period are summarized in figure 1.

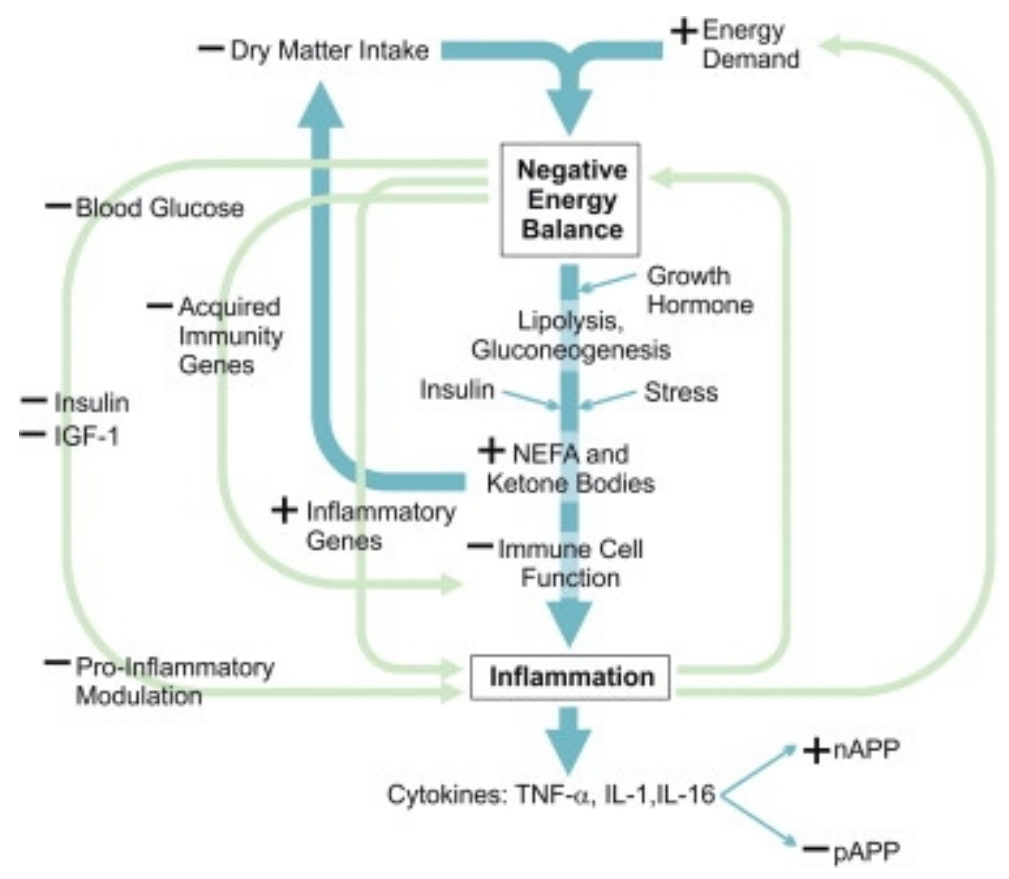

Figure 1. Major interactions between the immune, endocrine and metabolic systems in dairy cows during the transition period. Inflammation postpartum, high cellular metabolism and upregulated immune gene expression increase energy requirements when there is a reduced dry matter intake. The symbols + and - indicate an increase $(+)$ or a decrease (-) in biomolecule levels. NEFA, non esterified fatty acids; IGF-1, insulin-like growth factor 1; TNF$\alpha$, tumor necrosis factor $\alpha$; IL-1 and IL-6, interleukin 1 and 6; nAPP and PAPP, negative and positive acute phase proteins. 


\section{Metabolic and physiological changes during the transition period: Inflammation, energy balance, endocrine changes and immunosuppression}

The primary challenge faced by cows is a sudden increase of nutrient requirements for milk production at a time when dry matter intake (DMI) and nutrient supply lags behind. High nutrient demands for galactopoesis are accompanied with mobilization of body reserves to support milk production. Thus the cows enter a physiologically unavoidable negative energy balance status (Grummer et al., 2004; Ingvartsen, 2006). This is compounded by additional factors such as stress or management which further reduce DMI (West, 2003; Dobson et al., 2007; Rhoads et al., 2009). Inflammation and dysregulated immune responses have been proposed as the missing link in the pathobiolology of metabolic disorders in transition cows. Strong evidence has emerged of inflammatory mediators directly inducing metabolic disturbances (Trevisi et al., 2010). Many metabolic hormones and their receptors also alter in concentration over the peripartum period. In particular, interdependent changes occur in the $\mathrm{GH}$ insulin-IGF-I-glucose signaling pathway (Lucy et al., 2001). Nutrient demands in late pregnancy are in part met by an increased state of insulin resistance in adipose tissue and muscle, coupled with an increased sensitivity to lipolytic agents (Bell, 1995), which reduce peripheral glucose uptake and facilitate nutrient flow away from maternal stores to the placenta. The further demand for glucose after calving often leads to a fall in circulating insulin in early lactation. Genetic selection for milk production has also been associated with a decline in circulating insulin levels (Taylor et al., 2004). During NEB, however, the GH-IGF axis uncouples due to a down-regulation in liver GHR and this is associated with a reduction in circulating IGF-I and elevated GH concentrations (Lucy et al., 2001). This, coupled with the low prevailing insulin, provides an endocrine environment that promotes the direct action of GH on lipolysis and gluconeogenesis in early lactation. 
Leptin is another metabolic hormone of interest in relation to energy balance. Circulating concentration of leptin is strongly correlated to body condition score (BCS) and falls in late pregnancy (Ehrhardt et al., 2000; Wathes et al., 2007). However, leptin concentrations remain low postpartum even when the energy balance has improved (Ingvartsen and Boisclair, 2001; Wathes et al., 2007). Leptin can influence voluntary feed intake and may also contribute to the peripheral insulin resistance which occurs in peripartum ruminants (Blache et al., 2001; Ingvartsen and Boisclair, 2001).

Plasma progesterone levels, which are high during gestation, fall rapidly at calving and are accompanied by a transient estrogen and glucocorticoid increase. These hormonal changes not only contribute to the decline in DMI but also promote metabolic changes that favor the mobilization of body fat reserves from adipocytes (Drackley et al., 2005; Ingvartsen, 2006).

The transient temperature elevation in transition cows $\left(>39.5^{\circ} \mathrm{C}\right)$ in the days following calving is mainly due to common malaise conditions linked to inflammation and the release of pro-inflammatory cytokines such as a tumor necrosis factor alpha (TNF- $\alpha$ ), interleukines 1 and 6 (IL-1 and IL-6) (Trevisi et al., 2011). These cytokines stimulate hepatic synthesis of positive acute phase proteins (pAPP) such as haptoglobin and ceruloplasmin (Chan et al., 2004; Huzzey et al., 2009). Concomitantly, cytokines impair synthesis of negative acute phase proteins (nAPP) even though some of them are important for normal liver function.

Metabolic demands associated with late pregnancy, parturition and initiation of lactation are thought to increase the production of reactive oxygen species (ROS) (Sordillo, 2005). ROS can initiate lipid peroxidation and cause cellular damage to tissues. Immune cells are particularly sensitive to oxidative stress because their membranes contain high concentrations of polyunsaturated fatty acids that are very susceptible to peroxidation, and they produce large amounts of reactive oxygen species when 
stimulated (Spears and Weiss, 2008). In the periparturient period circulating levels of IgG and IgM decline (Herr et al., 2011), neutrophil function is impaired (Hoeben et al., 2000; Rinaldi et al., 2008) and there is neutrophilia and eosinopaenia (Meglia et al., 2005). Moreover, unhealthy cows have lower paraoxanase (PON) activity (Bionaz et al., 2007). This may be due to fat mobilization and triglyceride deposition in liver cells, which cause liver damage and dysfunction (Turk et al., 2004), reduction in total blood cholesterol and high density lipoproteins (HDL) (Turk et al., 2005) to which PON is bound in the blood, associated with an increase in oxidative stress (Turk et al., 2004, 2005) or a combination of these.

Due to the lower levels of circulating IGF-I, not only is the proinflammatory response modulated by this hormone lowered but the onset of the first ovulation after parturition is also delayed (Kawashima et al., 2007; O’Connor et al., 2008).

Inflammation postpartum, coupled with the increased cellular metabolism, upregulated immune gene expression and mitochondrial uncoupling further increase energy requirements (Puigserver et al., 2001; Drackley, 2006; Ingvartsen, 2006). Thus postpartum inflammation exacerbates negative energy status (Trevisi et al., 2007, 2010) while carbohydrate insufficiency increases production of non-esterified fatty acids (NEFA) and ketone bodies in the liver (Duffield and Herdt, 2000; Drackley et al., 2001). The NEB and high plasma NEFA contribute to the development of fatty liver syndrome which in turn is a contributing factor to other health concerns and periparturient immunosuppression in the postpartum period (Lacetera et al., 2005; Kehrli Jr et al., 2006;). Recent studies show that inflammatory immune genes are up-regulated in cows suffering severe NEB (Wathes et al., 2009), whereas genes involved in the acquired immune responses are down-regulated in NEB cows (Moyes et al., 2010) highlighting the key role of immune responses in transition cows. Furthermore, ketotic cows are immunosuppressed during the postpartum period. Leukocytes from naturally-occurring ketotic cows have lower chemotactic differentials than those from non-ketotic cows, and chemotactic capacity is impaired when leukocytes 
migrate in an environment with ketone bodies (Holtenius et al., 2004). Elevated plasma NEFA mimic intense lipomobilization and alter the ability of lymphocytes to proliferate or secrete immunoglobulin M and interferon- $\gamma$ in response to polyclonal stimulation (Lacetera et al., 2004) as well as the viability and oxidative burst of polymorphonuclear (PMN) cells (Scalia et al., 2006). It is thought that plasma NEFA's may be diagnostic markers of impaired periparturient immunity and increased risk of infections (Moyes et al., 2009; Ospina et al., 2010). In particular, pre and postpartum serum NEFA concentrations higher than 0.3 and $0.6 \mathrm{mmol} / \mathrm{l}$ respectively, are associated with increased risk for displaced abomasum, clinical ketosis, retained placenta and metritis (Ospina et al., 2010). Given that the occurrence of diseases in periparturient cows center on the three principal axes of disproportional energy metabolism, disturbed mineral utilization and perturbed immune function, there is a need for further research to identify ways of regulating immune responses for preventing transition diseases.

Because the disorders mentioned above are interrelated and can occur as a complex in one animal or in a herd, herd health management strategies designed to prevent these diseases are urgently needed. To this end, an understanding of the complex immunological processes at play in the transition cow is a must.

\section{Metabolic disorders associated with energy nutrition}

\subsection{Ketosis and fatty liver syndrome}

Ketosis is the imbalanced use of body fat by a cow common in early lactation and is characterized by hypoglycemia and hyperketonemia (Kehrli Jr et al., 2006). Insufficient blood glucose levels induce a decline in plasma insulin, and mobilization of triacylglycerol deposits as NEFA (Block and Sanchez, 2000). Complete oxidation of NEFA generates the metabolite acetyl coenzyme $A$ that can be used to generate energy via the Krebs cycle. However, if the Krebs cycle gets overloaded the acetyl Co A is diverted to 
produce ketones (acetoacetic acid, acetone, and $\beta$-hydroxybutyrate or BHB). If ketones are elevated, clinical ketosis ensues (Block, 2010). At least 50\% of all dairy cows are thought to go through a temporary period of subclinical ketosis in the first month of lactation. This adaptive strategy is remarkably successful in maintaining blood glucose; despite the large increase in demand circulating concentrations of glucose generally only show a brief fall for around 1-2 weeks at calving. Pronounced accumulation of fat in the liver hamper metabolism and impair immune responses (Zerbe et al., 2000). Therefore to prevent ketosis and fatty liver syndrome it is necessary to avoid excessive weight loss in the peripartal period. Management practices which aim to optimize dry matter intake (DMI), increase the energy density of the diets without sacrificing rumen function, and maintain body condition score at 3.5 on the 1-5 scale at calving are recommended (Macdonald and Roche, 2004).

\subsection{Rumen acidosis}

Ruminal acidosis can present in different forms ranging from peracute life-threatening to chronic forms. The subclinical form of acidosis (SARA) is present in a large number of dairy cows with impaired immune function (Krause and Oetzel, 2006). In postpartum cows, the onset of acidosis is marked by dampened immune response, depressed intake of a low fiber or high energy diet when the rumen is still adapting to transition changes. When switching from a dry-period to an early lactation diet, the mucosa of the rumen will not have adapted yet, as the papillae are too short and the resorbing surface too small to deal with the sudden increase of short-chain fatty acids (SCFA) levels (Nordlund et al., 1995). The local microbial population, needed to metabolize the lactic acid arising from the fermentation of abundant carbohydrates, lags behind, thus disturbing the balance between production and absorption of fermentation end products (Nordlund et al., 1995; Nagaraja and Titgemeyer, 2007). Thus, in cases of SARA, these mechanisms cannot prevent a transient fall of ruminal $\mathrm{pH}$ to ranges below $\mathrm{pH} 5.5$, a level at 
which rumen function is lowered. The ruminal microflora can be characterized as cellulolytic developing a $\mathrm{pH}$ within the higher physiological range when fermenting a diet with a high content of structured feedstuffs. The feed-intake of the periparturient cow varies considerably and is difficult to estimate, especially when cows are kept in larger groups. Because cattle select concentrates out of component feeding, concentrate intake may be higher than scheduled. In farms feeding total mixed rations the number of variants of the lactational diets is limited, making phased changes of dietary composition impossible. Therefore, instead of being adapted gradually to the high-energy diet, the cows in the early post-partum period may be confronted with a rapidly rising energy-content of the ration (Rollin, 2006). The combination of lack of adaptation of the rumen to concentrates and a high concentrate intake around parturition against a backdrop of general low feed intake may lead to development of SARA in the post-partum period.

\subsection{Displaced abomasum}

Left-displaced abomasum (LDA) is a disorder that occurs mainly in high producing dairy cows postpartum (Geishauser, 1995). In postpartum cows the abomasum may shift to the left without causing overt clinical signs (Van Wimden et al., 2002). The early postpartum period is considered to be the major

risk period, because hypocalcemia, metritis, negative energy balance and nutritional factors play a central role in the pathogenesis of LDA (Shaver, 1997). The effects of impaired immune responses in LDA are unknown. Nearly $50 \%$ of the LDA cases are accompanied by NEB (Heuer, 2000). BHBA and aspartate aminotransferase (ASAT) activity in the blood, both parameters associated with NEB of postpartum cows, may be used to predict the development of LDA (Geishauser et al., 2000). Diagnosis of LDA is difficult because the sensitivity and specificity of these markers in predicting a subsequent LDA in the 
second week after calving are low $(\mathrm{BHBA}>1.0 \mathrm{mmol} / \mathrm{l}$ : sensitivity $=0.64$ and specificity $=0.69$, ASAT $>100 \mathrm{U} / \mathrm{l}$ : sensitivity $=0.79$ and specificity $=0.69)$ (Geishauser et al., 2000).

\section{Infectious diseases linked to immunosuppression}

It is well documented that a number of components of the host defense system are altered during the transition period, including neutrophyl functions, lymphocyte responsiveness to mitogen stimulation, antibody responses and cytokine production by immune cells (Lacetera et al., 2005; Goff, 2006; Kehrli Jr et al., 2006; Mulligan and Doherty, 2008). This is thought to be the main reason for the high prevalence of infections, primarily metritis or mastitis, during the early postpartum period (Kimura et al., 2002). Immunosuppression together with marked changes in endocrinological, nutritional and metabolic status cause increased concentrations of circulating cortisol around parturition (Waller, 2002). These dynamic changes seem to be central to the metabolic disturbances (e.g., NEB, hypocalcemia) which favor establishment of infection in the postpartum cow (Burton et al., 2005; Goff, 2006; Spears and Weiss, 2008).

\section{Immune response of the postpartum uterus}

Establishment of microbial infections in the reproductive tract can have negative consequences for reproductive function of the postpartum female (Kasimanickam et al., 2004; Dobson et al., 2008; Gautam et al., 2009). In a large study involving 5,719 postpartum dairy cows, it was observed that first service pregnancy rate was $39.4 \%$ for cows diagnosed with metritis in the first $65 \mathrm{~d}$ postpartum, $38.7 \%$ for cows diagnosed with clinical endometritis and $51.4 \%$ for cows in which no disease was diagnosed during the first 65 d postpartum (Santos et al., 2010). Compromised systemic immune function is a 
cause of uterine diseases. In one study, peripheral blood leukocytes of cows that developed endometritis were less capable of phagocytosis prepartum than those of cows that did not develop endometritis (Kim et al., 2005). Cows that subsequently developed metritis had reduced glycogen content in circulating neutrophils at calving (Galvão et al., 2010) and reduced expression of TNF $\alpha$ by $E$. coli-stimulated monocytes (Galvão et al., 2012).

The early postpartum female has also just completed a prolonged period when immune function in the uterus is suppressed because of the need to limit maternal immune responses against the allogeneic conceptus. Among the regulatory processes responsible for inhibition is an immunosuppressive role for progesterone (Majewski and Hansen, 2002; Padua et al., 2005) as well as differentiation of regulatory immune cells that can inhibit inflammation and T cell responses. Among these cells are the M2 macrophage (Gustafsson et al., 2008; Oliveira et al., 2010), ү $\delta$ T cell (Lee et al., 1992; Suzuki et al., 1995), and Treg cell (Aluvihare et al., 2004; Shima et al., 2010; Samstein et al., 2012). Some of the immunological adjustments to the presence of the conceptus also make the uterus more susceptible to bacterial infection. Thus, for example, progesterone not only depresses skin graft rejection but also reduces uterine capacity to eliminate bacterial infections (Lewis, 2003). The M2 macrophages can inhibit inflammation and facilitate persistence of some microbial infections (Varin and Gordon, 2009).

The complex process of uterine involution begins immediately after calving and involves uterine contractions, physical shrinking, necrosis, sloughing of caruncular material, and regeneration of the endometrium (Sheldon, 2004). The process seems to be driven in part by bacterial invasion (Chapwanya et al., 2012). Under normal circumstances the number of cows with bacterial infection at 3 weeks postpartum should decline to $40 \%$ (Sheldon, 2004). However, in approximately 10 to $17 \%$ of all postpartum cows, conditions favoring bacterial growth persist and cause endometritis (Sheldon et al., 2004). 
The immune system plays a major role in uterine defense mechanisms, although how this occurs is not fully understood. At the cellular level, defense against bacterial contaminants is provided by uterine leukocytes and polymorphonuclear cells (PMNs) that are the cells phagocytizing and clearing bacteria (Gilbert et al., 2007). PMNs are recruited to the infected uterus by chemotactic factors such as IL8 (Zerbe et al., 2003; Mette et al., 2010). This is an important chemo-attractant which increases the influx of PMNs and other leucocytes into the bovine uterus (Galvão et al., 2011). At the molecular level, interleukin-6 and TNF- $\alpha$ stimulate the production of antimicrobial peptides which assist in the elimination of pathogenic bacteria (Chapwanya et al., 2009; Sheldon et al., 2011). Pro-inflammatory cytokines such as IL-6, IL-8, and TNF- $\alpha$ may accelerate PMN infiltration into the bovine endometrium following infection (Fischer et al., 2010). The role of TNF- $\alpha$ is to stimulate the expression of IL-8 and molecular adhesion to vascular endothelial cells. Interleukin-8 plays an important role in PMNs and monocyte chemo-attraction and activation of PMNs and monocytes. These responses ultimately increase phagocytosis and bacterial killing (Roach et al., 2002; Sheldon et al., 2004; Galvão et al., 2011).

\subsection{Bacteriology of the postpartum uterus and pathogenesis of endometritis}

At partus, the vulva and cervix, which function as physical barriers together with the vestibule and vagina during pregnancy, relax and dilate, thus permitting bacterial influx into the uterus (Sheldon, 2004; Chapwanya et al., 2009). As such, intra- and postpartum bacterial contamination of the uterus is inevitable. Some studies report that the number of dairy cows with a uterine infection during the first 2 weeks postpartum is 80 to $100 \%$, even in the absence of calving difficulties (Sheldon, 2004; Földi et al., 2006) while all cows enrolled in other studies had positive endometrial bacterial culture 15 days after calving (Chapwanya et al., 2012). Immediately postpartum therefore the endometrium is the first line of 
defense against bacterial invaders (Sheldon et al., 2004; Chapwanya et al., 2009; Galvão et al., 2011; Sheldon et al., 2011).

In the first two weeks post-calving, positive endometrial cultures usually include one or more from $A$. pyogenes, Escherichia coli, Pseudomonas spp., Streptococcus spp., Staphylococcus spp., Pasteurella multocida, Clostridium spp., Fusobacterium spp. and Bacteroides spp.(LeBlanc, 2008; Chapwanya et al., 2012). The number and variety of bacteria diminishes substantially in healthy cows $3-4$ weeks postpartum (Chapwanya et al., 2012). In disease situations, A. pyogenes, Fusobacterium necrophorum and Prevotella melaninogenicus, E. coli or Streptococcus spp. occur singly or in combination (Bonnett et al., 1991; Williams et al., 2005). Recent studies show that E. coli infection in the first week postpartum and $A$. pyogenes in the second week cause severe endometritis (Gilbert et al., 2007; Williams et al., 2007). The presence of $A$. pyogenes alone beyond 3 weeks postpartum is associated with purulent vaginal discharge (Williams et al., 2005), persistent infection (Bonnett et al., 1991), elevated inflammation score in endometrial biopsies and perturbed fertility (Bonnett et al., 1993). Additionally, uterine infection and inflammation are associated with some alteration in the pattern of follicle growth on ovaries ipsilateral to the previous pregnancy, and disruption of subsequent luteal phase durations.

\subsubsection{Metritis}

Metritis (puerperal metritis) has been defined as an inflammation of the uterus resulting in systemic signs of sickness, including fever, red-brown watery foul-smelling enlarged uterus with a watery or purulent discharge, dullness, inappetance, elevated heart rate, and low production in the first 7 days after calving (Sheldon et al., 2006a). There may be predisposing factors such as retained placentas, fetal maceration, or difficult calving (Földi et al., 2006; Sheldon et al., 2006a; Sheldon et al., 2006b; Chapwanya, 2008). There is a link between feed intake and subsequent development of metritis (Huzzey 
et al., 2007; Huzzey et al., 2009). Cows with severe metritis eat 2-6 kg DM less than healthy cows in the 2-3 weeks preceding the clinical signs of metritis (Huzzey et al., 2007). Therefore management practices for periparturient dairy cows should be geared towards optimizing feed intake, particularly dry matter.

\subsubsection{Endometritis}

Clinical endometritis is the inflammation of the uterus without systemic illness, characterized by purulent or mucopurulent discharge or a cervical diameter $>7.5 \mathrm{~cm}$ after 20 days postpartum (DIM), or mucopurulent discharge after 26 DIM (LeBlanc et al., 2002). Histological changes include endometrial epithelial disruption, leukocyte infiltration, and vascular congestion and edema (Bonnett et al., 1991; Bondurant, 1998). It is not clear whether NEB exaggerates these changes. Subclinical endometritis has been defined as the presence of leukocytes, mainly PMNs, within the uterine lumen, but without clinical signs of endometritis (Földi et al., 2006; Sheldon et al., 2006b; Chapwanya, 2008).

There is recent evidence that endometritis is associated with reduced feed intake, severe negative energy balance, and disturbed immune function (Urton et al. , 2005; Hammon et al., 2006; Huzzey et al., 2007). It commonly occurs in high producing dairy cows more than 26 days postpartum (Sheldon et al., 2006b). Usually there is neither mortality nor direct loss of milk production due to endometritis (Fourichon et al., 2000). Meta-analysis studies show that endometritis increases mean number of days open by 15 days, decreases the relative risk of pregnancy by 150 days in milk by $31 \%$ and reduces pregnancy rate by $16 \%$ (Fourichon et al., 2000). The costs of endometritis include reproductive inefficiency, culling, treatment costs, milk discard, labour and increased risk of residues in food products.

\section{Possible nutritional strategies to improve the health of the transition cows}


The primary goal of nutritional management strategies of dairy cows during the transition period should be to support the metabolic adaptations that dairy cows face during this period. One possible intervention is manipulation of energy intake. The NRC (National Research Council, 2001) guidelines suggest that approximately $1.25 \mathrm{Mcal} / \mathrm{kg}$ of net energy for lactation (NEL) has to be fed from dry off until approximately $21 \mathrm{~d}$ before calving, and that a diet containing 1.54 to $1.62 \mathrm{Mcal} / \mathrm{kg}$ of NEL has to be fed during the last 3 wk preceding parturition. Feeding a lower energy diet during the early dry period minimizes body condition gain during the dry period. Furthermore, Dann et al. (2003) reported that supplying excessive energy to dairy cows during the early dry period may have detrimental carryover effects during the subsequent early lactation period. While the nature of these carryover effects is not known, one could speculate that effects could be mediated through the metabolic machinery responsible for tissue responsiveness to endocrine signals during the late prepartum period. Results from two experiments indicated farm-specific negative effects on subsequent production and health if cows were fed the higher energy diet for the entire dry period (Contreras et al., 2004) or for an average of 37 d prepartum (Mashek and Beede, 2001; Mashek et al., 2002). These responses may correspond to the negative carryover effects of overfeeding energy during the early dry period described by Dann and collaborators (2003). Recent results (Contreras et al., 2004) support managing cows to achieve a body condition score of approximately 3.0 at dry off rather than the traditional 3.5 to 3.75 . This may be partially due to the decreased DMI associated with higher body condition during the prepartum period (Hayirli et al., 2002). Figure 2, adapted from Allen and coworkers (2009) and Calder (2006) summarize the mechanism of action of the most common nutritional supplementation strategies discussed below. 


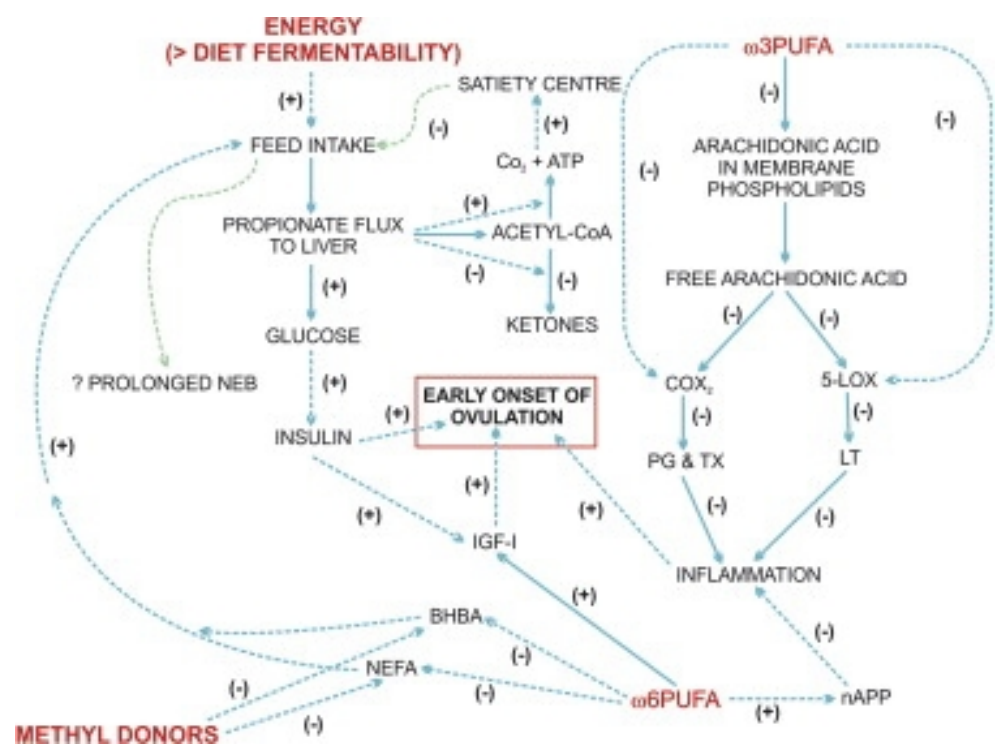

Figure 2. Mechanism of action of some of the most common nutritional supplementation strategies. Solid lines indicate a direct effect, while dashed lines indicate an indirect effect. The symbols + and - show an increase $(+)$ or a decrease (-). Furthermore, $\mathrm{COX}_{2}$ indicates cycloxigenates-2; 5-LOX stays for 5-Lypoxigenase; PG and TX indicate prostaglandins and thromboxane; LT stays for leukotriene.

\subsection{Carbohydrate formulation of the prepartum diet.}

A concept that has been perpetuated through the scientific literature (Rabelo et al., 2003) is that diets higher in non- fiber carbohydrates (NFC) content than traditional dry cow diets must be fed prior to calving to promote development of ruminal papillae for adequate absorption of volatile fatty acids produced during ruminal fermentation. Regardless of the effect on rumen epithelium, feeding diets containing higher proportions of NFC should promote ruminal microbial adaptation to NFC levels typical of lactation diets. These increased amounts of propionate support hepatic gluconeogenesis and the production of microbial protein, providing the diet contains sufficient rumen-degradable protein, which in turn satisfies protein requirements for maintenance, pregnancy, and mammogenesis. Hayirli and collaborators (2002), reported that prepartum DMI was positively correlated with NFC content of the 
prepartum diet. Nonetheless, Overton and Waldron (2004) highlighted that the generally positive effects on performance and metabolism of feeding diets during the prepartum period that are moderately higher in NFC content are linked to energy supply from carbohydrate rather than NFC content of the diet per se. This speculation is consistent with results reported recently by Pickett and coworkers (2003), who measured positive effects on metabolism and performance when NDF from forage was replaced by NDF from non-forage fiber sources in diets fed during the prepartum period.

However, optimal dietary concentration of the fermentable carbohydrates fiber, sugar, and starch is under investigation for the transition cows. It was suggested that optimizing DMI requires different diets at different stages of the lactation because DMI is controlled by oxidation of fuels (fatty acids, propionate, lactate, and amino acids) in the liver in early lactation and by gut fill as lactation approaches peak (Allen et al., 2009). Limiting dietary starch content and starch fermentability may increase DMI in early lactation since there is less rapid production and absorption of propionate (Allen et al., 2009). Nonetheless, more fermentable carbohydrates such as starch, non-forage fiber, and highly digestible forages should be fed later in lactation when plasma NEFA and BHBA decrease. Increasing the ruminal starch availability in a diet containing adequate physically effective NDF fed during the first 2 to 3 months may improve milk yield and fertility. Increasing the supply of glucogenic nutrients relative to lipogenic nutrients in early lactation may improve energy balance, decrease metabolic disorders, and improve reproduction through earlier resumption of the estrus cycle. Gong (2002) showed that feeding a higher starch diet (26 vs. 10\%) increased blood insulin concentration in early lactation and increased the proportion of cows that ovulated with the first $50 \mathrm{~d}$ postpartum. An increase in dietary glucogenic nutrients (27\% starch) in grass and corn silage-based diets fed through 9 wk postpartum improved energy status assessed by calculated energy balance, plasma NEFA and BHBA concentrations, and liver triglyceride content, but did not affect DMI or milk yield (Van Knegsel et al., 2007). Although increasing insulin by dietary manipulation can be beneficial for resumption of the estrous cycle, there is evidence that a high insulin status might have a detrimental effect on oocyte quality and embryo development (Santos et al., 
2010). Garnsworthy and coworkers (2009) demonstrated that pregnancy rate was improved when a glucogenic diet that stimulated plasma insulin was fed before the first ovulation postpartum followed by a lipid-rich diet that lowered plasma insulin during the breeding period. Caution is advised when formulating early lactation diets to stimulate the recrudescence of ovarian activity since highly fermentable starch diets fed immediately after calving may decrease DMI and prolong NEB (Allen et al., 2009).

\subsection{Fat supplementation in transition diet}

Conjugated linoleic acids (CLA) are a family of at least 28 isomers of linoleic acid (Banni, 2002). Lately, researchers have been focusing mainly on the isomers cis-9, trans-11 and the trans-10, cis-12. Feeding these isomers in a rumen-protected form to transition dairy cows reduces negative energy balance and NEFA and BHB levels in blood (Mattos et al., 2000; Castaneda-Gutierrez et al., 2007; Trevisi and Bertoni, 2008; Esposito et al., 2013). CLA supplementation increases DMI and some of the negative acute phase proteins such as albumin and cholesterol (Trevisi and Bertoni, 2008; Esposito et al., 2013). Moreover, in vitro studies showed that CLA have a beneficial role in protecting PON1 from oxidative inactivation, as well as in its stabilization in a concentration-dependent action against various oxidative inactivation systems (Su et al., 2003; Nguyen and Sok, 2004). Other researchers also showed that CLA inhibits lipopolysaccharide-induced inflammatory activity in RAW 264.7 macrophages and that it partially occurs through CLA modulating the nuclear transcription factor ${ }_{-k} B$ (Cheng et al., 2004). Collectively, these fatty acids may have roles important for the secretion of apolipoprotein B100 and also for VLDL particle stability in cultured hepatocytes (Wu et al., 1997). Consistent with these effects, incubation of ruminant hepatocytes in vitro demonstrated a potential role of linolenic acid in decreasing cellular accumulation of triglycerides from palmitic acid (Mashek et al., 2002). Short-term cultures of liver slices from immediate postpartal cows displayed decreased capacity for fatty acid esterification when incubated with a mixture of linoleic and linolenic acids (Piepenbrink and Overton, 2003). Moreover, eicosapentaenoic acid (EPA) and docosahexanoic acid (DHA) are known to decrease the amount of 
arachidonic acid in cell membranes. On a molecular level, these fatty acids also decrease the production of classical inflammatory cytokines tumor necrosis factor (TNF) and interleukin-6 (IL6). They also decrease the expression of adhesion molecules involved in inflammatory interactions between leukocytes and endothelial cells (Calder, 2006). The $\omega 3$ PUFA may modulate the expression of inflammatory genes by down-regulating activation of some transcription factors (Sethi et al., 2002) and inflammatory cytokines (Zhao et al., 2005). It is speculated that they directly target the inflammatory gene expression pathways trough Toll-like Receptor 4 (Lee and Hwang, 2006). More recently, diets enriched with $\omega 3$ fatty acids have been reported to modulate immune responses, such as LPS-induced febrile response (Farran et al., 2008). The effect of fish-oil on cell-mediated immune response has been investigated in periparturient dairy goats (Agazzi et al., 2004), where it has been shown to modify the ratio between mononuclear and polymorphonuclear cells and to improve some aspects of the cellmediated immune response. Yet, EPA and DHA may have beneficial effect on neutrophil function by increasing their phagocytosis activity and decreasing the tissue damages due to extracellular release of reactive oxygen species (ROS).

\subsection{Methyl donors}

Choline is a quasi-vitamin that has a variety of functions in mammalian metabolism. Its most significant functions are as a component of phosphatidylcholine which is the predominant phospholipid contained in cell membranes in the body, a component of the neurotransmitter acetylcholine, and as the direct precursor to betaine in methyl metabolism. Most of the potential application of choline within transition cow nutrition has focused on its role in lipid metabolism because phosphatidylcholine is required for synthesis and release of VLDL by the liver. Choline deficiency in rats resulted in a six-fold increase in liver triglyceride content (Yao and Vance, 1990), and in vitro incubation of hepatocytes isolated from choline- 
deficient rats with the methyl donors choline or methionine increased concentrations of phosphatidylcholine in liver and release of VLDL (Donkin, 2002). Yields of milk and fat-corrected milk have generally increased in response to feeding rumen-protected choline during the transition period (Hartwell et al., 2000; Piepenbrink and Overton, 2003; Pinotti et al., 2003; Scheer et al., 2002), suggesting that the metabolic changes in hepatic fatty acid metabolism translated into improved performance during early lactation. Methionine and lysine are frequently considered to be the most limiting amino acids for synthesis of milk and milk protein (National Research Council, 2001). These two amino acids also have potential roles in mitochondrial B-oxidation of fatty acids (carnitine biosynthesis) in liver and export of triglycerides as VLDL (apolipoprotein B100 biosynthesis) (Bauchart et al., 1998). A potential role for methionine in bovine ketosis has been speculated for more than 30 years (McCarthy et al., 1968; Waterman and Schultz, 1972). Investigators that have sought to increase the supply of methionine as either rumen- protected methionine (Overton et al., 1996; Socha et al., 1994) or its analog [2-hydroxy-4-(methylthio)butanoic acid] (Piepenbrink et al., 2004), beginning prior to parturition and continuing through early lactation generally reported increased milk yield during early lactation. These positive responses in production do not appear to relate directly to effects of methionine and lysine on hepatic lipid or glucose metabolism (Bertics and Grummer, 1999; Piepenbrink et al., 2004; Socha et al., 1994). Therefore, specific roles for methionine and lysine in aspects of hepatic lipid and glucose metabolism remain speculative and unsubstantiated.

\section{Conclusions}

Production diseases of the transition dairy cow which cause economic losses are underpinned by inflammatory immune responses. There is a need for nutrition strategies which reduce susceptibility to production diseases. Our understanding of the interactions between nutrition and immunity remains superficial. Reliable tools to assess the immune status of the cow must be developed to elucidate the 
immune responses of peripartal disorders. Integrative approaches at the molecular, cellular and animal level to unravel the complex interactions of metabolic and immune function underpinning periparturient diseases are warranted.

\section{Conflict of Interest}

The authors (Giulia Esposito, Pete Irons, Edward Webb, Aspinas Chapwanya) have no financial or personal relationship with other people or organizations that could inappropriately influence or bias the paper entitled "Interactions between negative energy balance, metabolic diseases, uterine health and immune response in transition dairy cows".

\section{Acknowledgments}

Funds provided by the Institute of Food, Nutrition and Wellbeing (IFNuW) from the University of Pretoria, South Africa.

\section{References}

Agazzi, A., Cattaneo, D., Dell’Orto, V., Moroni, P., Bonizzi, L., Pasotto, D., Bronzo, V., Savoini, G., 2004. Effect of administration of fish oil on aspects of cell-mediated immune response in periparturient dairy goats. Small Ruminant Res. 55, 77-83.

Allen, M., Bradford, B., Oba, M., 2009. The hepatic oxidation theory of the control of feed intake and its application to ruminants. J. Anim. Sci. 87, 3317-3334. 
Aluvihare, V.R., Kallikourdis, M., Betz, A.G., 2004. Regulatory T cells mediate maternal tolerance to the fetus. Nat. Immunol. 5, 266-271.

Banni, S., 2002. Conjugated linoleic acid metabolism. Curr. Opin. Lipidol. 13, 261-266.

Bauchart, D., Durand, D., Gruffat, D., Chilliard, Y., 1998. Mechanism of liver steatosis in early lactation cows--effects of hepatoprotector agents. Proceedings of the 60th C.N. C., 27-37.

Bell, A.W., 1995. Regulation of organic nutrient metabolism during transition from late pregnancy to early lactation. J. Anim. Sci. 73, 2804.

Bertics, S.J., Grummer, R.R., 1999. Effects of fat and methionine hydroxy analog on prevention or alleviation of fatty liver induced by feed restriction. J. Dairy Sci. 82 (12), 2731-2736.

Bertoni, G., Trevisi, E., Han, X., Bionaz, M., 2008. Effects of inflammatory conditions on liver activity in puerperium period and consequences for performance in dairy cows. J. Dairy Sci. 91, 3300-3310.

Bertoni, G., Trevisi, E., Lombardelli, R., 2009. Some new aspects of nutrition, health conditions and fertility of intensively reared dairy cows. Ital. J. Anim. Sci. 8, 491-518.

Bionaz, M., Trevisi, E., Calamari, L., Librandi, F., Ferrari, A., Bertoni, G., 2007. Plasma paraoxonase, health, inflammatory conditions, and liver function in transition dairy cows. J. Dairy Sci. 90, 1740-1750.

Blache, D., Celi, P., Blackberry, M.A., Dynes, R.A., Martin, G.B., 2001. Decrease in voluntary feed intake and pulsatile luteinizing hormone secretion after intracerebroventricular infusion of recombinant bovine leptin in mature male sheep. Reprod. Fert. Develop. 12, 373-381. 
Block, E., Sanchez, W., 2000. Special nutritional needs of the transition cow. Middle South Nutrition Conference, Dallas, TX.

Block, E., 2010. Transition cow research-what makes sense today. Proceedings of the High Plains Dairy Conference, Armarillo, TX , 75-98.

Bondurant, R., 1998. Inflammation in the bovine female reproductive tract. J. Dairy Sci. 82, 101-110.

Bonnett, B.N., Martin, S.W., Gannon, V., Miller, R.B., Etherington, W.G., 1991. Endometrial biopsy in Holstein-Friesian dairy cows. III. Bacteriological analysis and correlations with histological findings . Can. J. Vet. Res. 55, 168.

Bonnett, B.N., Wayne Martin, S., Meek, A.H., 1993. Associations of clinical findings, bacteriological and histological results of endometrial biopsy with reproductive performance of postpartum dairy cows. Prev. Vet. Med. 15, 205-220.

Burton, J.L., Madsen, S.A., Chang, L.C., Weber, P.S.D., Buckham, K.R., van Dorp, R., Hickey, M.C., Earley, B., 2005. Gene expression signatures in neutrophils exposed to glucocorticoids: a new paradigm to help explain "neutrophil dysfunction" in parturient dairy cows. Vet. Immunol. Immunop. 105, 197-219.

Butler, W.R., 2000. Nutritional interactions with reproductive performance in dairy cattle. Anim. Reprod. Sci. 60-61, 449-457.

Butler, S.T., Marr, A.L., Pelton, S.H., Radcliff, R.P., Lucy, M.C., Butler, W.R., 2003. Insulin restores GH responsiveness during lactation-induced negative energy balance in dairy cattle: effects on expression of IGF-I and GH receptor 1A. J. Endocrinol. 176, 205-217. 
Calder, P.C., 2006. n- 3 polyunsaturated fatty acids, inflammation, and inflammatory diseases. American J. Clin. Nutr. 83, S1505-1519S.

Castaneda-Gutierrez, E., Benefield, B.C., de Veth, M.J., Santos, N.R., Gilbert, R.O., Butler, W.R., Bauman, D.E., 2007. Evaluation of the mechanism of action of conjugated linoleic acid isomers on reproduction in dairy cows. J. Dairy Sci. 90, 4253-4264.

Chagas, L., Bass, J., Blache, D., Burke, C., Kay, J., Lindsay, D., Lucy, M., Martin, G., Meier, S., Rhodes, F., 2007. Invited Review: New Perspectives on the Roles of Nutrition and Metabolic Priorities in the Subfertility of High-Producing Dairy Cows. J. Dairy Sci. 90, 4022-4032.

Chan, J.P.W., Chu, C.C., Fung, H.P., Chuang, S.T., Lin, Y.C., Chu, R.M., Lee, S.L., 2004. Serum haptoglobin concentration in cattle. J. Vet. Med. Sci. 66, 43-46.

Chapwanya, A., 2008. Uterine disease in dairy cows: Classification, diagnosis and key roles for veterinarians. Irish Vet. J. 61, 183.

Chapwanya, A., Meade, K.G., Doherty, M.L., Callanan, J.J., Mee, J.F., O’Farrelly, C., 2009. Histopathological and molecular evaluation of Holstein-Friesian cows postpartum: toward an improved understanding of uterine innate immunity. Theriogenology 71, 1396-1407.

Chapwanya, A., Meade, K.G., Foley, C., Narciandi, F., Evans, A.C.O., Doherty, M.L., Callanan, J.J., O'Farrelly, C., 2012. The postpartum endometrial inflammatory response: a normal physiological event with potential implications for bovine fertility. Reprod. Fert. Develop. 24 (8), 1028-1039. 
Cheng, W.L., Lii, C.K., Chen, H.W., Lin, T.H., Liu, K.L., 2004. Contribution of conjugated linoleic acid to the suppression of inflammatory responses through the regulation of the NF-KB pathway. J. Agr. Food Chem. $52,71-78$.

Contreras, L., Ryan, C., Overton, T., 2004. Effects of dry cow grouping strategy and prepartum body condition score on performance and health of transition dairy cows. J. Dairy Sci. 87, 517-523.

Dann, H., Litherland, N., Underwood, J., Bionaz, M., Drackley, J., 2003. Prepartum nutrient intake has minimal effects on postpartum dry matter intake, serum nonesterified fatty acids, liver lipid and glycogen contents, and milk yield. J. Dairy Sci. 86, 106.

Dantzer, R., Kelley, K.W., 2007. Twenty years of research on cytokine-induced sickness behaviour. Brain Behav. Immun. 21 (2), 153-160.

Dobson, H., Smith, R., Royal, M., Knight, C., Sheldon, I., 2007. The High-producing Dairy Cow and its Reproductive Performance. Reprod. Domest. Anim. 42, 17-23.

Dobson, H., Walker, S., Morris, M., Routly, J., Smith, R., 2008. Why is it getting more difficult to successfully artificially inseminate dairy cows? Animal 2, 1104-1111.

Donkin, S.S., 2002. Rumen-protected choline: Potential for improving health and production in dairy cows. Proceeding of Tri-state Dairy Nutrition Conference, Ft. Wayne IN 55-65.

Drackley, J.K., 1999. Biology of dairy cows during the transition period: the final frontier? J. Dairy Sci. 82, 2259-2273.

Drackley, J.K., Overton, T.R., Douglas, G.N., 2001. Adaptations of glucose and long-chain fatty acid metabolism in liver of dairy cows during the periparturient period. J. Dairy Sci. 84, E100-E112. 
Drackley, J.K., Dann, H.M., Neil Douglas, G., Janovick Guretzky, N.A., Litherland, N.B., Underwood, J.P., Loor, J.J., 2005. Physiological and pathological adaptations in dairy cows that may increase susceptibility to periparturient diseases and disorders. Ital. J. Anim. Sci. 4.

Drackley, J., 2006. Advances in transition cow biology: new frontiers in production diseases. Production disease in farms animals. Wageningen Academic Publishers, Wageningen, The Netherlands, 24-34.

Duffield, T., Herdt, T., 2000. Subclinical ketosis in lactating dairy cattle. Vet. Clin. N. Am.-Food A. 16, 231253.

Ehrhardt, R., Slepetis, R., Siegal-Willott, J., Van Amburgh, M., Bell, A., Boisclair, Y., 2000. Development of a specific radioimmunoassay to measure physiological changes of circulating leptin in cattle and sheep. J. Endocrinol. 166, 519-528.

Esposito, G., Schneider, A., Absalôn Medina, V.A., Pelton, S.H., Butler, W.R., 2013. Effect of dietary conjugated linoleic acid on reproduction and tissue responses in dairy cows. S. Afr. J. Anim. Sci. 43 (1), 33-37.

Farran, T., Reinhardt, C., Blasi, D., Minton, J., Elsasser, T., Higgins, J., Drouillard, J., 2008. Source of dietary lipid may modify the immune response in stressed feeder cattle. J. Anim. Sci. 86, 1382-1394.

Fischer, C., Drillich, M., Odau, S., Heuwieser, W., Einspanier, R., Gabler, C., 2010. Selected proinflammatory factor transcripts in bovine endometrial epithelial cells are regulated during the oestrous cycle and elevated in case of subclinical or clinical endometritis. Reprod. Fert. Develop. 22, 818-829.

Földi, J., Kulcsar, M., Pecsi, A., Huyghe, B., De Sa, C., Lohuis, J., Cox, P., Huszenicza, G., 2006. Bacterial complications of postpartum uterine involution in cattle. Anim. Reprod. Sci. 96, 265-281. 
Fourichon, C., Seegers, H., Malher, X., 2000. Effect of disease on reproduction in the dairy cow: a metaanalysis. Theriogenology 53, 1729-1759.

Galvão, K., Flaminio, M., Brittin, S., Sper, R., Fraga, M., Caixeta, L., Ricci, A., Guard, C., Butler, W., Gilbert, R., 2010. Association between uterine disease and indicators of neutrophil and systemic energy status in lactating Holstein cows. J. Dairy Sci. 93, 2926-2937.

Galvão, K., Santos, N., Galvão, J., Gilbert, R., 2011. Association between endometritis and endometrial cytokine expression in postpartum Holstein cows. Theriogenology 76, 290-299.

Galvão, K., Felippe, M., Brittin, S., Sper, R., Fraga, M., Galvão, J., Caixeta, L., Guard, C., Ricci, A., Gilbert, R., 2012. Evaluation of cytokine expression by blood monocytes of lactating Holstein cows with or without postpartum uterine disease. Theriogenology 77, 356-372.

Garnsworthy, P., Fouladi-Nashta, A., Mann, G., Sinclair, K. \& Webb, R. 2009. Effect of dietary-induced changes in plasma insulin concentrations during the early post-partum period on pregnancy rate in dairy cows. Reproduction 137, 759-768.

Gautam, G., Nakao, T., Yusuf, M., Koike, K., 2009. Prevalence of endometritis during the postpartum period and its impact on subsequent reproductive performance in two Japanese dairy herds. Anim. Reprod. Sci. 116, 175-187.

Geishauser, T., 1995. Abomasal displacement in the bovine-a review on character, occurrence, aetiology and pathogenesis. J. Vet. Med. A 42, 229-251.

Geishauser, T., Leslie, K., Duffield, T., 2000. Prevention and prediction of displaced abomasum in dairy cows. Bovine Pr. 34, 51-55. 
Gilbert, R., Santos, N., Galvão, K., Brittin, S., Roman, H., 2007. The relationship between postpartum uterine bacterial infection (BI) and subclinical endometritis (SE). J. Dairy Sci. 90, 469.

Goff, J., 2006. Major advances in our understanding of nutritional influences on bovine health. J. Dairy Sci. 89, 1292-1301.

Gong, J.G. 2002. Influence of metabolic hormones and nutrition on ovarian follicle development in cattle: practical implications. Domest. Anim. Endocrin. 23, 229-241.

Gröhn, Y., Rajala-Schultz, P., Allore, H., DeLorenzo, M., Hertl, J., Galligan, D., 2003. Optimizing replacement of dairy cows: modeling the effects of diseases. Prev. Vet. Med. 61, 27-43.

Grummer, R.R., Mashek, D.G., Hayirli, A., 2004. Dry matter intake and energy balance in the transition period. Vet. Clin. N Am.-Food A. 20 (3), 447-470.

Gustafsson, C., Mjösberg, J., Matussek, A., Geffers, R., Matthiesen, L., Berg, G., Sharma, S., Buer, J., Ernerudh, J., 2008. Gene expression profiling of human decidual macrophages: evidence for immunosuppressive phenotype. PLoS One 3 (4), e2078.

Hammon, D., Evjen, I., Dhiman, T., Goff, J., Walters, J., 2006. Neutrophil function and energy status in Holstein cows with uterine health disorders. Vet. Immunol. Immunop. 113, 21-29.

Hartwell, J., Cecava, M., Donkin, S., 2000. Impact of dietary rumen undegradable protein and rumenprotected choline on intake, peripartum liver triacylglyceride, plasma metabolites and milk production in transition dairy cows. J. Dairy Sci. 83, 2907-2917. 
Hayirli, A., Grummer, R., Nordheim, E., Crump, P., 2002. Animal and dietary factors affecting feed intake during the prefresh transition period in Holsteins. J. Dairy Sci. 85, 3430-3443.

Herr, M., Bostedt, H., Failing, K., 2011. IgG and IgM levels in dairy cows during the periparturient period. Theriogenology 75, 377-385.

Heuer, C., 2000. Negative Energy Balance in Dairy Cows: Prediction, Consequences, Prevention. Utrecht University.

Hoeben, D., Monfardini, E., Opsomer, G., Burvenich, C., Dosogne, H., de Kruif, A., Beckers, J.F., 2000. Chemiluminescence of bovine polymorphonuclear leucocytes during the periparturient period and relation with metabolic markers and bovine pregnancy-associated glycoprotein. J. Dairy Res. 67, 249259.

Holtenius, K., Persson Waller, K., Essén-Gustavsson, B., Holtenius, P., Hallén Sandgren, C., 2004. Metabolic parameters and blood leukocyte profiles in cows from herds with high or low mastitis incidence. Vet. J. 168, 65-73.

Huzzey, J., Veira, D., Weary, D., Von Keyserlingk, M., 2007. Prepartum behavior and dry matter intake identify dairy cows at risk for metritis. J. Dairy Sci. 90, 3220-3233.

Huzzey, J., Duffield, T., LeBlanc, S., Veira, D., Weary, D., von Keyserlingk, M., 2009. Short communication: Haptoglobin as an early indicator of metritis. J. Dairy Sci. 92, 621-625.

Ingvartsen, K.L., Boisclair, Y., 2001. Leptin and the regulation of food intake, energy homeostasis and immunity with special focus on periparturient ruminants. Domest. Anim. Endocrin. 21, 215-250. 
Ingvartsen, K.L., 2006. Feeding-and management-related diseases in the transition cow: Physiological adaptations around calving and strategies to reduce feeding-related diseases. Anim. Feed Sci. Tech. 126, 175-213.

Kasimanickam, R., Duffield, T., Foster, R., Gartley, C., Leslie, K., Walton, J., Johnson, W., 2004. Endometrial cytology and ultrasonography for the detection of subclinical endometritis in postpartum dairy cows. Theriogenology 62, 9-23.

Kawashima, C., Fukihara, S., Maeda, M., Kaneko, E., Montoya, C.A., Matsui, M., Shimizu, T., Matsunaga, N., Kida, K., Miyake, Y., 2007. Relationship between metabolic hormones and ovulation of dominant follicle during the first follicular wave post-partum in high-producing dairy cows. Reproduction 133, 155163.

Kehrli Jr, M., Neil, J., Burvenich, C., Goff, J., Lippolis, J., Reinhardt, T., Nonnecke, B., 2006. Energy and protein effects on the immune system. Ruminant physiology: Digestion, metabolism and impact of nutrition on gene expression, immunology and stress, Wageningen Academic Pub. 455-471.

Kim, I.H., Na, K.J., Yang, M.P., 2005. Immune responses during the peripartum period in dairy cows with postpartum endometritis. J. Reprod. Develop. 51, 757.

Kimura, K., Goff, J.P., Kehrli Jr, M.E., Reinhardt, T.A., 2002. Decreased neutrophil function as a cause of retained placenta in dairy cattle. J. Dairy Sci. $85,544-550$.

Krause, K.M., Oetzel, G.R., 2006. Understanding and preventing subacute ruminal acidosis in dairy herds: A review. Anim. Feed Sci. Tech. 126, 215-236. 
Lacetera, N., Scalia, D., Bernabucci, U., Ronchi, B., Pirazzi, D., Nardone, A., 2005. Lymphocyte functions in overconditioned cows around parturition. J. Dairy Sci. 88, 2010-2016.

Lacetera, N., Scalia, D., Franci, O., Bernabucci, U., Ronchi, B., Nardone, A., 2004. Short Communication: Effects of Nonesterified Fatty Acids on Lymphocyte Function in Dairy Heifers. J. Dairy Sci. 87, 1012-1014.

LeBlanc, S.J., 2008. Postpartum uterine disease and dairy herd reproductive performance: A review. Vet. J. 176, 102-114.

LeBlanc, S., Duffield, T., Leslie, K., Bateman, K., Keefe, G., Walton, J., Johnson, W., 2002. Defining and diagnosing postpartum clinical endometritis and its impact on reproductive performance in dairy cows. J. Dairy Sci. 85, 2223-2236.

Lee, C., Meeusen, E., Gogolin-Ewens, K., Brandon, M., 1992. Quantitative and qualitative changes in the intraepithelial lymphocyte population in the uterus of nonpregnant and pregnant sheep. Am. J. Reprod. Immunol. 28 (2), 90-96.

Lee, J.Y., Hwang, D.H., 2006. The modulation of inflammatory gene expression by lipids: mediation through Toll-like receptors. Mol. Cells 21 (2),174-185.

Lewis, G., 2003. Role of ovarian progesterone and potential role of prostaglandin F2 $\alpha$ and prostaglandin E2 in modulating the uterine response to infectious bacteria in postpartum ewes. J. Anim. Sci. 81, 285293.

Lopez-Gatius, F., 2003. Is fertility declining in dairy cattle?-A retrospective study in northeastern Spain. Theriogenology 60, 89-99. 
López-Gatius, F., García-Ispierto, I., Santolaria, P., Yániz, J., Nogareda, C., López-Béjar, M., 2006. Screening for high fertility in high-producing dairy cows. Theriogenology 65, 1678-1689.

Lucy, M., 2007. Fertility in high-producing dairy cows: reasons for decline and corrective strategies for sustainable improvement. Reproduction in Domestic Ruminants 6, 237-254.

Lucy, M., Jiang, H., Kobayashi, Y., 2001. Changes in the somatotrophic axis associated with the initiation of lactation. J. Dairy Sci. 84, E113-E119.

Macdonald, K., Roche, J., 2004. Condition scoring made easy. Dexcel Limited, Hamilton, New Zealand, pp. 37

Majewski, A., Hansen, P., 2002. Progesterone inhibits rejection of xenogeneic transplants in the sheep uterus. Horm. Res. in Paediatrics 58, 128-135.

Mashek, D., Beede, D., 2001. Peripartum responses of dairy cows fed energy-dense diets for 3 or 6 weeks prepartum. J. Dairy Sci. 84, 115-125.

Mashek, D., Bertics, S., Grummer, R., 2002. Metabolic fate of long-chain unsaturated fatty acids and their effects on palmitic acid metabolism and gluconeogenesis in bovine hepatocytes. J. Dairy Sci. 85, 2283-2289.

Mattos, R., Staples, C.R., Thatcher, W.W., 2000. Effects of dietary fatty acids on reproduction in ruminants. Reproduction 5 (1), 38-45.

McCarthy, R.D., Porter, G.A., Griel, L.C., 1968. Bovine ketosis and depressed fat test in milk: a problem of methionine metabolism and serum lipoprotein aberration. J. Dairy Sci. 51, 459-462. 
McCarthy, S., Berry, D., Dillon, P., Rath, M., Horan, B., 2007. Influence of Holstein-Friesian strain and feed system on body weight and body condition score lactation profiles. J. Dairy Sci. 90, 1859-1869.

Mee, J., 2007. The role of the veterinarian in bovine fertility management on modern dairy farms. Theriogenology 68, S257-S265.

Meglia, G., Johannisson, A., Agenäs, S., Holtenius, K., Waller, K.P., 2005. Effects of feeding intensity during the dry period on leukocyte and lymphocyte sub-populations, neutrophil function and health in periparturient dairy cows. Vet.J. 169 (3), 376-384.

Mette, C., Camilla Dooleweerdt, B., Stine, J., Anders Miki, B., Henrik, L.J., 2010. Evaluation of the systemic acute phase response and endometrial gene expression of serum amyloid $A$ and pro-and antiinflammatory cytokines in mares with experimentally induced endometritis. Vet. Immunol. Immunop. $138,95-105$.

Moyes, K., Larsen, T., Friggens, N., Drackley, J., Ingvartsen, K.L., 2009. Identification of potential markers in blood for the development of subclinical and clinical mastitis in dairy cattle at parturition and during early lactation. J. Dairy Sci. 92, 5419-5428.

Moyes, K.M., Drackley, J.K., Morin, D.E., Rodriguez-Zas, S.L., Everts, R.E., Lewin, H.A., Loor, J.J., 2010. Mammary gene expression profiles during an intramammary challenge reveal potential mechanisms linking negative energy balance with impaired immune response. Physiol. Genomics 41, 161-170.

Mulligan, F., Doherty, M., 2008. Production diseases of the transition cow. Vet. J. 176, 3-9.

Nagaraja, T., Titgemeyer, E., 2007. Ruminal Acidosis in Beef Cattle: The Current Microbiological and Nutritional Outlook ${ }^{1 \text { and } 2}$. J. Dairy Sci. 90, E17-E38. 
National Animal Health Monitoring System, Dairy 2007. Part I: Reference of Dairy Cattle Health and Management Practices in the United States, USDA/APHIS/VS/NAHMS Centers for Epidemiology and Animal Health, Fort Collins, CO .

National Research Council, 2001. Nutrient Requirements of Dairy Cattle, 7th rev. ed. ed. National Academy Press, Washington, DC.

Nguyen, S.D., Sok, D.E., 2004. Preferential inhibition of paraoxonase activity of human paraoxonase 1 by negatively charged lipids. J. Lipid Res. 45, 2211-2220.

Nordlund, K.V., Garrett, E.F., Oetzel, G.R., 1995. Herd-based rumenocentesis: A clinical approach to the diagnosis of subacute rumen acidosis. The Compendium on continuing education for the practicing veterinarian 17.

O'Connor, J.C., McCusker, R.H., Strle, K., Johnson, R.W., Dantzer, R., Kelley, K.W., 2008. Regulation of IGF-I function by proinflammatory cytokines: at the interface of immunology and endocrinology. Cell. Immunol. 252, 91-110.

Oliveira, L.J., McClellan, S., Hansen, P.J., 2010. Differentiation of the endometrial macrophage during pregnancy in the cow. PloS one 5, e13213.

Ospina, P., Nydam, D., Stokol, T., Overton, T., 2010. Evaluation of nonesterified fatty acids and $\beta$ hydroxybutyrate in transition dairy cattle in the northeastern United States: Critical thresholds for prediction of clinical diseases. J. Dairy Sci. 93, 546-554.

Overton, T., LaCount, D., Cicela, T., Clark, J., 1996. Evaluation of a ruminally protected methionine product for lactating dairy cows. J. Dairy Sci. 79, 631-638. 
Overton, T., Waldron, M., 2004. Nutritional management of transition dairy cows: strategies to optimize metabolic health. J. Dairy Sci. 87, E105-E119.

Padua, M.B., Tekin, Ş., Spencer, T.E., Hansen, P.J., 2005. Actions of progesterone on uterine immunosuppression and endometrial gland development in the uterine gland knockout (UGKO) ewe. Mol. Reprod. Dev. 71, 347-357.

Patton, J., Kenny, D.A., McNamara, S., Mee, J.F., O'mara, F.P., Diskin, M.G., Murphy, J.J., 2007. Relationships among milk production, energy balance, plasma analytes, and reproduction in HolsteinFriesian cows. J. Dairy Sci. 90 (2), 649-658.

Pickett, M., Cassidy, T., Tozer, P., Varga, G., 2003. Effect of prepartum dietary carbohydrate source and monensin on dry matter intake, milk production and blood metabolites of transition dairy cows. J. Dairy Sci. 86, 10.

Piepenbrink, M., Marr, A., Waldron, M., Butler, W., Overton, T., Vázquez-Añón, M., Holt, M., 2004. Feeding 2-hydroxy-4-(methylthio)-butanoic acid to periparturient dairy cows improves milk production but not hepatic metabolism. J. Dairy Sci. 87, 1071-1084.

Piepenbrink, M., Overton, T., 2003. Hepatic palmitate metabolism of periparturient dairy cows as affected by nutrients supplied in vitro. J. Dairy Sci. 86, 220.

Pinotti, L., Baldi, A., Politis, I., Rebucci, R., Sangalli, L., Dell'Orto, V., 2003. Rumen-Protected Choline Administration to Transition Cows: Effects on Milk Production and Vitamin E Status. J. Vet. Med. A 50, $18-21$.

Pittman, D.Q.J., 2011. A Neuro-Endocrine-Immune Symphony. J. Neuroendocrinol. 23, 1296-1297. 
Puigserver, P., Rhee, J., Lin, J., Wu, Z., Yoon, J.C., Zhang, C.Y., Krauss, S., Mootha, V.K., Lowell, B.B., Spiegelman, B.M., 2001. Cytokine stimulation of energy expenditure through p38 MAP kinase activation of PPAR [gamma] coactivator-1. Mol. Cells 8, 971-982.

Rabelo, E., Rezende, R., Bertics, S., Grummer, R., 2003. Effects of transition diets varying in dietary energy density on lactation performance and ruminal parameters of dairy cows. J. Dairy Sci. 86, 916.

Rajala-Schultz, P.J., Frazer, G.S., 2003. Reproductive performance in Ohio dairy herds in the 1990s. Anim. Reprod. Sci. 76, 127-142.

Rhoads, M., Rhoads, R., VanBaale, M., Collier, R., Sanders, S., Weber, W., Crooker, B., Baumgard, L., 2009. Effects of heat stress and plane of nutrition on lactating Holstein cows: I. Production, metabolism, and aspects of circulating somatotropin. J. Dairy Sci. 92, 1986-1997.

Rinaldi, M., Moroni, P., Paape, M.J., Bannerman, D.D., 2008. Differential alterations in the ability of bovine neutrophils to generate extracellular and intracellular reactive oxygen species during the periparturient period. Vet. J. 178, 208-213.

Roach, D.R., Bean, A.G.D., Demangel, C., France, M.P., Briscoe, H., Britton, W.J., 2002. TNF regulates chemokine induction essential for cell recruitment, granuloma formation, and clearance of mycobacterial infection. J. Immunol. 168, 4620-4627.

Rollin, F., 2006. Tools for a prompt cowside diagnosis: what can be implemented by the bovine practitioner. Proceedings of the 24th World Buiatrics Congress 75-85.

Royal, M., Mann, G.E., Flint, A.P., 2000. Strategies for reversing the trend towards subfertility in dairy cattle. Vet. J. 160, 53-60. 
Samstein, R.M., Josefowicz, S.Z., Arvey, A., Treuting, P.M., Rudensky, A.Y., 2012. Extrathymic generation of regulatory T cells in placental mammals mitigates maternal-fetal conflict. Cell 150, 29-38.

Santos, J., Bisinotto, R., Ribeiro, E., Lima, F., Greco, L., Staples, C., Thatcher, W., 2010. Applying nutrition and physiology to improve reproduction in dairy cattle. Reprod. Domest. Anim. 7, 385-401.

Scalia, D., Lacetera, N., Bernabucci, U., Demeyere, K., Duchateau, L., Burvenich, C., 2006. In Vitro Effects of Nonesterified Fatty Acids on Bovine Neutrophils Oxidative Burst and Viability1. J. Dairy Sci. 89, 147154.

Scheer, W., Lucy, M., Kerley, M., Spain, J., 2002. Effects of feeding soybeans and rumen protected choline during late gestation and early lactation on performance of dairy cows. J. Dairy Sci. 85, 276.

Sethi, S., Ziouzenkova, O., Ni, H., Wagner, D.D., Plutzky, J., Mayadas, T.N., 2002. Oxidized omega-3 fatty acids in fish oil inhibit leukocyte-endothelial interactions through activation of PPAR $\alpha$. Blood 100, 13401346.

Shaver, R., 1997. Nutritional risk factors in the etiology of left displaced abomasum in dairy cows: a review. J. Dairy Sci. 80, 2449-2453.

Sheldon, I.M., 2004. The postpartum uterus. Vet. Clin. N Am.-Food A 20, 569-591.

Sheldon, I., Bushnell, M., Montgomery, J., Rycroft, A., 2004. Minimum inhibitory concentrations of some antimicrobial drugs against bacteria causing uterine infections in cattle. Vet. Rec.. 155, 383-387. Sheldon, I., Rycroft, A., Zhou, C., 2004. Association between postpartum pyrexia and uterine bacterial infection in dairy cattle. Veterinary Record 154, 289-293. 
Sheldon, I.M., Lewis, G.S., LeBlanc, S., Gilbert, R.O., 2006a. Defining postpartum uterine disease in cattle. Theriogenology 65, 1516-1530.

Sheldon, I.M., Wathes, D.C., Dobson, H., 2006b. The management of bovine reproduction in elite herds. Vet. J. $171,70-78$

Sheldon, I.M., Cronin, J., Borges, A., 2011. The postpartum period and modern dairy cow fertility Part 1: Uterine function. Livest. Sci. 16, 14-18.

Shima, T., Sasaki, Y., Itoh, M., Nakashima, A., Ishii, N., Sugamura, K., Saito, S., 2010. Regulatory T cells are necessary for implantation and maintenance of early pregnancy but not late pregnancy in allogeneic mice. J. Reprod. Immunol. 85, 121-129.

Smith, J., Ely, L., Chapa, A., 2000. Effect of region, herd size, and milk production on reasons cows leave the herd. J. Dairy Sci. 83, 2980-2987.

Socha, M., Schwab, C., Putnam, D., Whitehouse, N., Kierstead, N., Garthwaite, B., 1994. Production responses of early lactation cows fed rumen-stable methionine or rumen-stable lysine plus methionine at two levels of dietary crude protein. J. Dairy Sci. 77, 93.

Sordillo, L.M., 2005. Factors affecting mammary gland immunity and mastitis susceptibility. Livest. Prod. Sci. 98, 89-99.

Spears, J.W., Weiss, W.P., 2008. Role of antioxidants and trace elements in health and immunity of transition dairy cows. Vet. J. 176, 70-76. 
Stofkova, A., 2009. Leptin and adiponectin: from energy and metabolic dysbalance to inflammation and autoimmunity. Endocrine Regulations 43, 157.

Su, N.D., Liu, X.W., Kim, M.R., Jeong, T.S., Sok, D.E., 2003. Protective action of CLA against oxidative inactivation of paraoxonase 1, an antioxidant enzyme. Lipids 38, 615-622.

Suzuki, T., Hiromatsu, K., Ando, Y., Okamoto, T., Tomoda, Y., Yoshikai, Y., 1995. Regulatory role of gamma delta T cells in uterine intraepithelial lymphocytes in maternal antifetal immune response. The J. Immunol. 154, 4476-4484.

Taylor, V., Beever, D., Wathes, D., Kebreab, E., Mills, J., 2004. Physiological adaptations to milk production that affect the fertility of high yielding dairy cows. Dairying: using science to meet consumers' needs. Conference Proceedings, University of Reading, UK,, 37-71.

Trevisi, E., Han, X., Piccioli-Cappelli, F., Bertoni, G., 2002. Intake reduction before calving affects milk yield and metabolism in dairy cows. , $53^{\text {rd }}$ EAAP annual meeting.

Trevisi, E., Gubbiotti, A., Bertoni, G., 2007. Effects of inflammation in peripartum dairy cows on milk yield, energy balance and efficiency. EAAP pubblication 124, 395.

Trevisi, E., Bertoni, G., 2008. Attenuation with acetylsalicylate treatments of inflammatory conditions in periparturient dairy cows. Aspirin and health research progress. Nova Science Publ., Hauppauge, NY, USA , 23-37.

Trevisi, E., Ferrari, A., Piccioli-Cappelli, F., Grossi, P., Bertoni, G., 2010. An additional study on the relationship between the inflammatory condition at calving time and net energy efficiency in dairy cows. Energy and Protein Metabolism and Nutrition. EAAP publication No.127 , 489-490. 
Trevisi, E., Amadori, M., Archetti, I., Lacetera, N., Bertoni, G., 2011. Inflammatory Response and Acute Phase Proteins in the Transition Period of High-Yielding Dairy Cows. Acute Phase Proteins as Early NonSpecific Biomarkers of Human and Veterinary Diseases 15, 355-379.

Turk, R., Juretic, D., Geres, D., Turk, N., Rekic, B., Simeon-Rudolf, V., Svetina, A., 2004. Serum paraoxonase activity and lipid parameters in the early postpartum period of dairy cows. Res. Vet. Sci. 76, 57-61.

Turk, R., Juretic, D., Geres, D., Turk, N., Rekic, B., Simeon-Rudolf, V., Robic, M., Svetina, A., 2005. Serum paraoxonase activity in dairy cows during pregnancy. Res. Vet. Sci. 79, 15-18.

Urton, G., Von Keyserlingk, M., Weary, D., 2005. Feeding behavior identifies dairy cows at risk for metritis. J. Dairy Sci. 88, 2843-2849.

Van Knegsel, A., Van den Brand, H., Dijkstra, J. \& Kemp, B. 2007. Effects of dietary energy source on energy balance, metabolites and reproduction variables in dairy cows in early lactation. Theriogenology, 68, S274-S280.

Van Wimden, S., Brattinga, C., Müller, K., Noordhuizen, J., Beynen, A., 2002. Position of the abomasum in dairy cows during the first six weeks after calving. Vet. Rec. 151, 446-449.

VanRaden, P., Sanders, A.H., Tooker, M.E, Miller, R., Norman, H.D., Kuhn, M., Wiggans, G., 2004. Development of a national genetic evaluation for cow fertility. J. Dairy Sci. 87, 2285-2292. 
VanRaden, P.M., Sanders, A.H., Tooker, M.E., Miller, R.H., Norman, H.D., 2011. Daughter pregnancy rate evaluation of cow fertility. USDA AIPL research report .

Varin, A., Gordon, S., 2009. Alternative activation of macrophages: immune function and cellular biology. Immunobiology 214, 630-641.

Waller, K.P., 2002. Mammary gland immunology around parturition. Biology of the Mammary Gland, 231-245.

Waterman, R., Schultz, L., 1972. Methionine hydroxy analog treatment of bovine ketosis: effects on circulating metabolites and interrelationships. J. Dairy Sci. 55, 1513-1516.

Wathes, D., Cheng, Z., Bourne, N., Taylor, V., Coffey, M., Brotherstone, S., 2007. Differences between primiparous and multiparous dairy cows in the inter-relationships between metabolic traits, milk yield and body condition score in the periparturient period. Domest. Anim. Endocrin. 33, 203-225.

Wathes, D.C., Cheng, Z., Chowdhury, W., Fenwick, M.A., Fitzpatrick, R., Morris, D.G., Patton, J., Murphy, J.J., 2009. Negative energy balance alters global gene expression and immune responses in the uterus of postpartum dairy cows. Physiol. Genomics 39, 1-13.

West, J., 2003. Effects of heat-stress on production in dairy cattle. J. Dairy Sci. 86, 2131-2144.

Williams, E.J., Fischer, D.P., Pfeiffer, D.U., England, G.C.W., Noakes, D.E., Dobson, H., Sheldon, I.M., 2005. Clinical evaluation of postpartum vaginal mucus reflects uterine bacterial infection and the immune response in cattle. Theriogenology 63, 102-117. 
Williams, E.J., Fischer, D.P., Noakes, D.E., England, G.C.W., Rycroft, A., Dobson, H., Sheldon, I.M., 2007. The relationship between uterine pathogen growth density and ovarian function in the postpartum dairy cow. Theriogenology 68, 549-559.

Wu, X., Shang, A., Jiang, H., Ginsberg, H.N., 1997. Demonstration of biphasic effects of docosahexaenoic acid on apolipoprotein B secretion in HepG2 cells. Arterioscl. Throm. Vas. 17, 3347-3355.

Yao, Z., Vance, D.E., 1990. Reduction in VLDL, but not HDL, in plasma of rats deficient in choline. Biochem. Cell Biol. 68, 552-558.

Zerbe, H., Schneider, N., Leibold, W., Wensing, T., Kruip, T., Schuberth, H., 2000. Altered functional and immunophenotypical properties of neutrophilic granulocytes in postpartum cows associated with fatty liver. Theriogenology 54, 771-786.

Zerbe, H., Schuberth, H.J., Engelke, F., Frank, J., Klug, E., Leibold, W., 2003. Development and comparison of in vivo and in vitro models for endometritis in cows and mares. Theriogenology 60, 209223.

Zhao, G., Etherton, T.D., Martin, K.R., Vanden Heuvel, J.P., Gillies, P.J., West, S.G., Kris-Etherton, P.M., 2005. Anti-inflammatory effects of polyunsaturated fatty acids in THP-1 cells. Biochem. Bioph. Res. Co. 336, 909-917. 